\title{
ВОПРОСЫ МЕДИЦИНСКОГО ОБРАЗОВАНИЯ
}

УДК 378.12

\section{Н. Э. Голованова ${ }^{1}$, О. А. Лобанова ${ }^{2}$, И. В. Астратенкова ${ }^{1}$ \\ ОСНОВНЫЕ КАЧЕСТВА ПРЕПОДАВАТЕЛЯ \\ ПО МНЕНИЮ СТУДЕНТОВ МЕДИЦИНСКИХ ФАКУЛЬТЕТОВ}

${ }^{1}$ Санкт-Петербургский государственный университет, Российская Федерация, 199034, Санкт-Петербург, Университетская наб., 7-9

${ }^{2}$ Северо-Западный государственный медицинский университет им. И. И. Мечникова, Российская Федерация, 191015, Санкт-Петербург, Кирочная ул., 41

В статье обсуждаются результаты анкетирования студентов медицинских факультетов вузов Санкт-Петербурга об основных качествах преподавателя. Анкета содержала 37 качеств, которые были разделены на 4 блока: профессионально-компетентностные, организаторские, личностные, коммуникативные. По мнению студентов наиболее важными оказались профессионально-компетентностные и отдельные коммуникативные качества. Наименее важными - личностные, такие как «имидж, стиль одежды», «личное обаяние», «принципиальность». Оценивался оптимальный возраст преподавателя и предпочтительный стиль общения с точки зрения студентов. Для 70 \% участников опроса возраст преподавателя не имеет значения. Приоритетный стиль общения - демократический. Библиогр. 9 назв. Ил. 3. Табл. 3.

Ключевые слова: качества преподавателя, профессионально-компетентностные, личностные, коммуникативные, организаторские, студенты, анкетирование.

\section{BASIC TEACHER'S QUALITIES IN THE OPINION OF MEDICAL STUDENTS}

\author{
N.E. Golovanova ${ }^{1}$, O. A. Lobanova ${ }^{2}$, I. V. Astratenkova ${ }^{1}$ \\ ${ }^{1}$ St Petersburg State University, 7-9, Universitetskaya nab., St. Petersburg, 199034, Russian Federation \\ ${ }^{2}$ I. I. Menshikov North-Western State Medical University, 41, Kirochnaya ul., St.-Petersburg, 191015, \\ Russian Federation
}

The article discusses the results of the survey of medical students of two St. Petersburg universities about the basic teacher's qualities. The questionnaire contained 37 characteristics. They were distributed into 4 blocks: professional competency, organizational qualities, personal qualities, communication. The professional competency and some communication skills were the most important qualities. The least important qualities were personal qualities, such as "image, style of clothing", "charm", "integrity". In this survey the optimal teacher's age and the optimal style of communication from the point of view of the students were evaluated. Regarding the age of the lecturer, $70 \%$ reported that it did not matter. The preferable style of communication was the democratic style. Refs 9. Figs 3. Tables 3.

Keywords: teacher's qualities, professional competency, organizational qualities, personal qualities, communication, students, survey. 


\section{Введение}

Современный образовательный процесс предполагает индивидуально-ориентированное образование с переходом от парадигмы обучения к парадигме учения. При этом основная роль в образовании переходит к обучающемуся - студенту. В ходе обучения студенты приобретают квалификацию, которая в Федеральном законе «Об образовании в РФ» трактуется, как уровень знаний, умений, навыков и компетенций, характеризующий подготовленность выпускника [1]; поэтому основная цель преподавателей вузов - оснастить выпускников инструментами профессии - компетенциями.

Формирование компетенций начинается уже на первых курсах. Задача первых курсов обучения - дать студенту возможность овладеть фундаментальными знаниями, которые лягут в основу будущей профессиональной деятельности [2]. Обучение на медицинских факультетах для студентов начинается с освоения большого количества теоретических дисциплин: гистологии, анатомии, биохимии, физиологии и др. Это предполагает наличие весомого количества понятий, терминов и требует от студентов больших усилий по запоминанию [3]. На этом этапе роль преподавателя в первую очередь заключается в построении учебного процесса таким образом, чтобы помочь студенту сориентироваться и разобраться в массиве изучаемой информации.

В профессиональной среде обсуждается вопрос об изменении роли непосредственного общения с преподавателями в ходе учебного процесса, так как увеличивается доля самостоятельной работы студентов, дистанционных форм обучения, более доступной становится информация благодаря интернету, в том числе благодаря видеолекциям [4-6]. Это приводит и к изменению отношения студентов к преподавателям. Студенты по-другому воспринимают и по другим качествам оценивают их деятельность $[7,8]$. Этим и обусловлена актуальность выявления наиболее востребованных среди современного российского студенчества качеств личности вузовского преподавателя [9].

\section{Методы исследования}

Цель нашего исследования - определение качеств преподавателя, значимых в процессе обучения по мнению самих студентов-медиков. Был проведен опрос студентов второго курса медицинских факультетов Санкт-Петербургского государственного университета (СПбГУ) и Северо-Западного государственного медицинского университета (СЗГМУ) имени И.И. Мечникова (специальность «лечебное дело») с использованием анкеты (табл. 1).

В анкете предлагалось оценить 37 качеств преподавателя, которые были разделены на 4 блока: профессионально-компетентностные, организаторские, личностные и коммуникативные. В опросе участвовало 24 студента СПбГУ и $23-$ СЗГМУ имени И.И. Мечникова. Качества оценивали по балльной системе: 2 - «очень важно», 1 - «важно», 0 - «не важно». Результаты выражали средним баллом и процентным соотношением.

\section{1. Профессионально-компетентностные:}

- умение заинтересовать;

- знание своего предмета; 
Уважаемые студенты, какие качества преподавателя Вы считаете наиболее важными? Обведите, пожалуйста, 2, 1 или 0 в зависимости от важности для Вас лично перечисленных качеств

\begin{tabular}{|c|c|c|c|}
\hline Качества & $\begin{array}{l}\text { Очень } \\
\text { важно }\end{array}$ & Важно & $\begin{array}{c}\mathrm{He} \\
\text { важно }\end{array}$ \\
\hline 1. Умение заинтересовать & 2 & 1 & 0 \\
\hline 2. Уравновешенность & 2 & 1 & 0 \\
\hline 3. Знание своего предмета & 2 & 1 & 0 \\
\hline 4. Доброжелательность & 2 & 1 & 0 \\
\hline 5. Умение организовать и вести диалог на занятии & 2 & 1 & 0 \\
\hline 6. Использование современных научных данных & 2 & 1 & 0 \\
\hline 7. Готовность отвечать на вопросы & 2 & 1 & 0 \\
\hline 8. Умение организовать самостоятельную работу & 2 & 1 & 0 \\
\hline 9. Чувство юмора & 2 & 1 & 0 \\
\hline 10. Любовь к своей профессии & 2 & 1 & 0 \\
\hline 11. Грамотное изложение материала & 2 & 1 & 0 \\
\hline 12. Использование на занятии игровых элементов & 2 & 1 & 0 \\
\hline 13. Объективность & 2 & 1 & 0 \\
\hline 14. Использование примеров из практики, собственного & & & \\
\hline опыта & 2 & 1 & 0 \\
\hline 15. Умение создать атмосферу доверия на занятии & 2 & 1 & 0 \\
\hline $\begin{array}{l}\text { 16. Использование на занятии наглядных пособий (схем, } \\
\text { таблиц, приборов, рисунков и т. д.) }\end{array}$ & 2 & 1 & 0 \\
\hline 17. Профессиональная ориентация материала & 2 & 1 & 0 \\
\hline 18. Наличие четкого плана занятия & 2 & 1 & 0 \\
\hline 19. Личное обаяние & 2 & 1 & 0 \\
\hline 20. Доступное изложение материала & 2 & 1 & 0 \\
\hline 21. Соблюдение оптимального темпа занятия & 2 & 1 & 0 \\
\hline 22. Справедливость & 2 & 1 & 0 \\
\hline 23. Внимательное выслушивание студента & 2 & 1 & 0 \\
\hline 24. Пунктуальность, соблюдение временных рамок занятия & 2 & 1 & 0 \\
\hline 25. Принципиальность & 2 & 1 & 0 \\
\hline 26. Умение объяснить задачи на занятии & 2 & 1 & 0 \\
\hline 27. Уверенность в себе & 2 & 1 & 0 \\
\hline 28. Тактичность & 2 & 1 & 0 \\
\hline 29. Оптимальное сочетание теоретического и практического & & & \\
\hline материала & 2 & 1 & 0 \\
\hline 30. Убедительное изложение материала & 2 & 1 & 0 \\
\hline 31. Четкость, конкретность вопросов & 2 & 1 & 0 \\
\hline 32. Имидж, стиль одежды & 2 & 1 & 0 \\
\hline 33. Интеллигентность & 2 & 1 & 0 \\
\hline 34. Умение держать дистанцию при общении & 2 & 1 & 0 \\
\hline 35. Логичность, последовательность изложения материала & 2 & 1 & 0 \\
\hline
\end{tabular}

36. Возраст: моложе 30 лет, 30-40 лет, 40-50 лет, старше 50 лет, не важно.

37. Стиль общения: авторитарный, демократический, либеральный, не важно.

Укажите, пожалуйста, свой курс , факультет

\section{СПАСИБО}


- использование современных научных данных;

- любовь к своей профессии;

- использование примеров из практики, собственного опыта;

- профессиональная ориентация материала.

2. Организаторские:

- умение организовать и вести диалог на занятии;

- умение организовать самостоятельную работу;

- использование на занятии игровых элементов;

- использование на занятии наглядных пособий (схемы, таблицы, приборы, рисунки и т.д.);

- наличие четкого плана занятия;

- соблюдение оптимального темпа занятия;

- пунктуальность, соблюдение временных рамок занятия;

- оптимальное сочетание теоретического и практического материала.

3. Личностные:

- уравновешенность;

- чувство юмора;

- объективность;

- обаяние;

- справедливость;

- принципиальность;

- уверенность в себе;

- тактичность;

- интеллигентность;

- возраст.

4. Коммуникативнье:

- доброжелательность;

- готовность отвечать на вопросы;

- грамотное изложение материала;

- умение создать атмосферу доверия на занятии;

- доступность в изложении материала;

- внимательное выслушивание студента;

- умение объяснить задачи на занятии;

- убедительное изложение материала;

- четкость, конкретность вопросов;

- имидж, стиль одежды;

- умение держать дистанцию при общении;

- логичность, последовательность изложения материала;

- стиль общения.

\section{Результаты и их обсуждение}

Результаты исследования представлены в табл. 2.

Как видно из таблицы, наиболее важными качествами преподавателя студенты считают: 1) «знание своего предмета»; 2) «умение заинтересовать»; 3) «доступность в изложении материала»; 4) «логичность, последовательность изложения ма- 
териала». Таким образом, студенты выбрали те качества, которые необходимы им для эффективного освоения учебного материала и достижения максимальных результатов. Кроме того, большой приоритет получают преподаватели, которые профессионально ориентируют материал и преподают современные научные данные. В оценке этих качеств ни один студент не выбрал вариант «не важно». Обращает на себя внимание, что ответ «не важно» отсутствует и в отношении оптимального сочетания теоретического и практического материала. Это еще раз подтверждает тот факт, что студенты заинтересованы в усвоении материала, который является наиболее профессионально ориентированным.

Таблица 2. Результаты анкетирования студентов, \%

\begin{tabular}{|c|c|c|c|c|c|c|}
\hline \multirow{2}{*}{ Качества } & \multicolumn{2}{|c|}{ Очень важно } & \multicolumn{2}{|c|}{ Важно } & \multicolumn{2}{|c|}{ Не важно } \\
\hline & СЗГМУ & СПбгу & СЗгму & СПбгу & СЗГму & СПбгу \\
\hline Умение заинтересовать & 95 & 96 & 5 & 4 & 0 & 0 \\
\hline Знание своего предмета & 100 & 96 & & 4 & 0 & 0 \\
\hline $\begin{array}{l}\text { Использование современных } \\
\text { научных данных }\end{array}$ & 77 & 82 & 23 & 18 & 0 & 0 \\
\hline $\begin{array}{l}\text { Профессиональная ориентация } \\
\text { материала }\end{array}$ & 68 & 96 & 32 & 4 & 0 & 0 \\
\hline $\begin{array}{l}\text { Использование примеров } \\
\text { из практики, собственного опыта }\end{array}$ & 54 & 39 & 46 & 52,3 & 0 & 8,7 \\
\hline Любовь к своей профессии & 50 & 73 & 45,5 & 22,7 & 4,5 & 4,3 \\
\hline $\begin{array}{l}\text { Умение организовать и вести } \\
\text { диалог на занятии }\end{array}$ & 81 & 61 & 19 & 34,7 & 0 & 4,3 \\
\hline $\begin{array}{l}\text { Умение организовать } \\
\text { самостоятельную работу }\end{array}$ & 40 & 35 & 55,5 & 60,7 & 4,5 & 4,3 \\
\hline $\begin{array}{l}\text { Использование на занятии игровых } \\
\text { элементов }\end{array}$ & 18 & 13 & 37 & 48 & 45 & 39 \\
\hline $\begin{array}{l}\text { Использование на занятии } \\
\text { наглядных пособий }\end{array}$ & 68 & 69 & 32 & 26,7 & 0 & 4,3 \\
\hline Наличие четкого плана занятия & 50 & 69 & 50 & 26,7 & 0 & 4,3 \\
\hline $\begin{array}{l}\text { Соблюдение оптимального темпа } \\
\text { занятия }\end{array}$ & 50 & 65 & 50 & 30,7 & 0 & 4,3 \\
\hline $\begin{array}{l}\text { Пунктуальность, соблюдение } \\
\text { временных рамок занятия }\end{array}$ & 27 & 26 & 51 & 57 & 22 & 17 \\
\hline $\begin{array}{l}\text { Оптимальное сочетание } \\
\text { теоретического и практического } \\
\text { материала }\end{array}$ & 68 & 56 & 32 & 44 & 0 & 0 \\
\hline Уравновешенность & 81 & 65 & 19 & 35 & 0 & 0 \\
\hline Чувство юмора & 32 & 35 & 55 & 52 & 13 & 13 \\
\hline Объективность & 77 & 78 & 18,5 & 17,7 & 4,5 & 4,3 \\
\hline Обаяние & 22 & 22 & 42 & 65 & 36 & 13 \\
\hline Справедливость & 59 & 61 & 41 & 34,7 & 0 & 4,3 \\
\hline Принципиальность & 13 & 8,7 & 50 & 61,3 & 37 & 30 \\
\hline Уверенность в себе & 45 & 56 & 46 & 39,7 & 9 & 4,3 \\
\hline Тактичность & 68 & 48 & 32 & 47,7 & 0 & 4,3 \\
\hline
\end{tabular}


Окончание табл. 2

\begin{tabular}{|l|c|c|c|c|c|c|}
\hline \multirow{2}{*}{ Качества } & \multicolumn{2}{|c|}{ Очень важно } & \multicolumn{2}{c|}{ Важно } & \multicolumn{2}{c|}{ Не важно } \\
\cline { 2 - 8 } & СЗГМУ & СПбГУ & СЗГМУ & СПбГУ & СЗГМУ & СПбГУ \\
\hline Доброжелательность & 59 & 43 & 41 & 57 & 0 & 0 \\
\hline Готовность отвечать на вопросы & 77 & 56 & 8,5 & 35,3 & 4,5 & 8,7 \\
\hline Грамотное изложение материала & 54 & 69 & 37 & 26,7 & 9 & 4,3 \\
\hline $\begin{array}{l}\text { Умение создавать атмосферу } \\
\text { доверия на занятии }\end{array}$ & 54 & 48 & 37 & 43,3 & 9 & 8,7 \\
\hline $\begin{array}{l}\text { Доступность в изложении } \\
\text { материала }\end{array}$ & 86 & 96 & 14 & 4 & 0 & 0 \\
\hline $\begin{array}{l}\text { Внимательное выслушивание } \\
\text { студента }\end{array}$ & 63 & 65 & 28 & 35 & 9 & 0 \\
\hline $\begin{array}{l}\text { Умение объяснить задачи на } \\
\text { занятии }\end{array}$ & 73 & 74 & 27 & 17,3 & 0 & 8,7 \\
\hline Убедительное изложение материала & 50 & 43 & 50 & 52,7 & 0 & 4,3 \\
\hline Четкость, конкретность вопросов & 50 & 39 & 37 & 61 & 13 & 0 \\
\hline Имидж, стиль одежды & 0 & 4,3 & 41 & 30,7 & 59 & 65 \\
\hline $\begin{array}{l}\text { Умение держать дистанцию при } \\
\text { общении }\end{array}$ & 13 & 26 & 60 & 48 & 27 & 26 \\
\hline $\begin{array}{l}\text { Логичность, последовательность } \\
\text { изложения материала }\end{array}$ & 100 & 87 & 0 & 13 & 0 & 0 \\
\hline
\end{tabular}

Наименее важным студенты посчитали «имидж, стиль одежды». В среднем $62 \%$ в отношении этого показателя выбрали вариант «не важно».

Стоит отметить, что использование на занятии игровых элементов $42 \%$ анкетированных также посчитали неважным. Возможно, это связано с тем, что студенты не отнесли к этой категории решение ситуационных задач, хотя данная форма занятия пользуется у них успехом.

На рис. 1 представлены вышеперечисленные качества преподавателя с указанием среднего балла, который они получили по результатам опроса студентов двух вузов.

Рассмотрение распределения результатов по блокам показало, что наибольший балл получили качества 1 блока - профессионально-компетентностные (табл. 3). Такое распределение демонстрирует, что студенты в первую очередь воспринимают преподавателя как профессионала в определенной области медицинских знаний. Это может быть связано с их заинтересованностью получить максимум теоретических и практических навыков, необходимых им в будущей профессии.

Остальные блоки оказались примерно равнозначными. Это связано с большим разбросом в оценках качеств внутри блоков. В каждом блоке есть качества, которые студенты считают очень важными, а также маловажными. Так, в блоке 2 важным отметили оптимальное сочетание теоретического и практического материала, наименее важным - использование на занятии игровых элементов. В блоке 3 - довольно низкие баллы получило такое качество, как принципиальность, и при этом высокие баллы - объективность и справедливость. Не оставили без внимания студенты и такую характеристику личности преподавателя, как чувство юмора, а $13 \%$ опрошенных считают это качество не важным. 


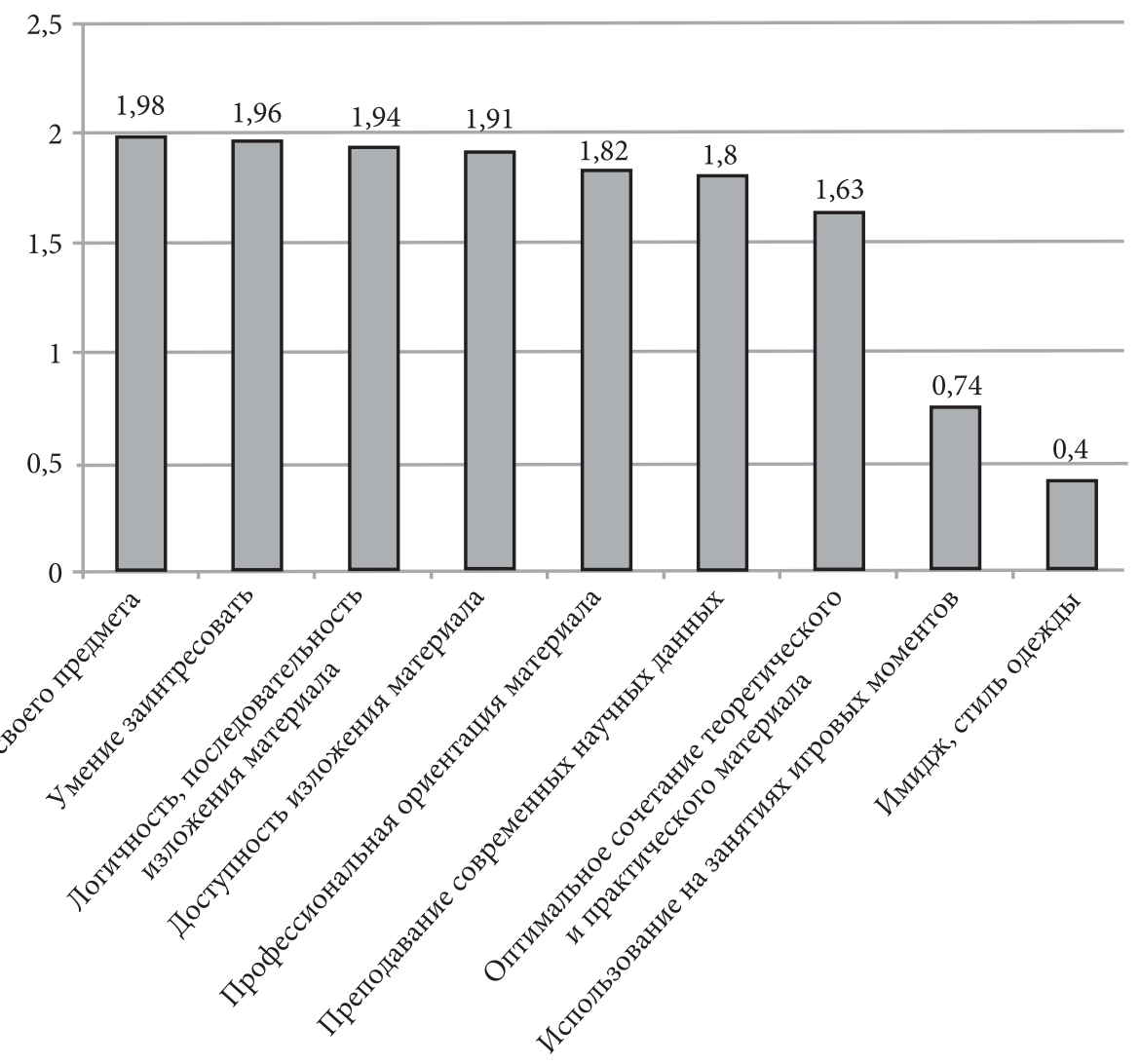

Puc. 1. Качества преподавателя, которые студенты двух вузов оценивают как наиболее и наименее важные

Таблица 3. Распределение результатов анкетирования по блокам, средний балл

\begin{tabular}{|l|c|c|c|}
\hline \multicolumn{1}{|c|}{ Качества } & СЗГМУ & СПбГУ & Итого \\
\hline \multicolumn{1}{|c|}{ Блок 1. Профессионально-компетентностные качества } \\
\hline Умение заинтересовать & 1,95 & 1,96 & 1,96 \\
\hline Знание своего предмета & 2,0 & 1,96 & 1,98 \\
\hline Преподавание современных научных данных & 1,77 & 1,83 & 1,8 \\
\hline Профессиональная ориентация материала & 1,68 & 1,96 & 1,82 \\
\hline $\begin{array}{l}\text { Использование примеров из практики, } \\
\text { собственного опыта }\end{array}$ & 1,55 & 1,3 & 1,43 \\
\hline Любовь к своей профессии & 1,45 & 1,7 & 1,58 \\
\hline \multicolumn{4}{|c|}{ Всего (блок 1) } \\
\hline \multicolumn{4}{|c|}{ Блок 2. Организаторские качества } \\
\hline Умение организовать и вести диалог на занятии & 1,82 & 1,76 & \\
\hline Умение организовать самостоятельную работу & 1,36 & 1,3 & 1,33 \\
\hline Использование на занятии игровых элементов & 0,73 & 0,74 & 0,74 \\
\hline Использование на занятии наглядных пособий & 1,68 & 1,65 & 1,67 \\
\hline
\end{tabular}


Окончание табл. 3

\begin{tabular}{|c|c|c|c|}
\hline Качества & СЗГМУ & СПбгу & Итого \\
\hline Наличие четкого плана занятия & 1,5 & 1,65 & 1,58 \\
\hline Соблюдение оптимального темпа занятия & 1,5 & 1,61 & 1,56 \\
\hline $\begin{array}{l}\text { Пунктуальность, соблюдение временных рамок } \\
\text { занятия }\end{array}$ & 1,05 & 1,09 & 1,07 \\
\hline $\begin{array}{l}\text { Оптимальное сочетание теоретического } \\
\text { и практического материала }\end{array}$ & 1,68 & 1,57 & 1,63 \\
\hline Всего (блок 2) & & 1,41 & \\
\hline \multicolumn{4}{|c|}{ Блок 3. Личностные качества } \\
\hline Уравновешенность & 1,82 & 1,65 & 1,74 \\
\hline Чувство юмора & 1,18 & 1,22 & 1,2 \\
\hline Объективность & 1,73 & 1,74 & 1,74 \\
\hline Обаяние & 0,86 & 1,09 & 0,98 \\
\hline Справедливость & 1,59 & 1,57 & 1,58 \\
\hline Принципиальность & 0,82 & 0,78 & 0,8 \\
\hline Уверенность в себе & 1,36 & 1,52 & 1,44 \\
\hline Тактичность & 1,68 & 1,43 & 1,56 \\
\hline Интеллигентность & 1,0 & 1,17 & 1,09 \\
\hline Всего (блок 3) & \multicolumn{3}{|c|}{1,46} \\
\hline \multicolumn{4}{|c|}{ Блок 4. Коммуникативные качества } \\
\hline Доброжелательность & 1,59 & 1,43 & 1,51 \\
\hline Готовность отвечать на вопросы & 1,73 & 1,48 & 1,61 \\
\hline Грамотное изложение материала & 1,45 & 1,65 & 1,55 \\
\hline Умение создавать атмосферу доверия на занятии & 1,45 & 1,39 & 1,42 \\
\hline Доступность изложения материала & 1,86 & 1,96 & 1,91 \\
\hline Внимательное выслушивание студента & 1,55 & 1,65 & 1,6 \\
\hline Умение объяснить задачи на занятии & 1,73 & 1,65 & 1,69 \\
\hline Убедительное изложение материала & 1,5 & 1,39 & 1,45 \\
\hline Четкость, конкретность вопросов & 1,36 & 1,39 & 1,38 \\
\hline Имидж, стиль одежды & 0,41 & 0,39 & 0,4 \\
\hline Умение держать дистанцию при общении & 0,86 & 1,0 & 0,93 \\
\hline $\begin{array}{l}\text { Логичность, последовательность изложения } \\
\text { материала }\end{array}$ & 2,0 & 1,87 & 1,94 \\
\hline Всего (блок 4) & \multicolumn{3}{|c|}{1,44} \\
\hline
\end{tabular}

Наибольший разброс баллов наблюдается в коммуникативном блоке. Среди наиболее важных качеств - логичность, последовательность изложения материала (1,94 балла) и доступность изложения (1,91 балла); а наименее важными оказались имидж и стиль одежды (0,4 балла).

Сравнение результатов опроса студентов двух медицинских вузов большой разницы в ответах не выявило. В целом тенденция носит сходный характер. Однако имеют место некоторые отличия. Например, качества «уравновешенность», «умение организовать и вести диалог на занятии», «тактичность», «четкость, конкретность вопросов» для студентов СЗГМУ оказались более важными, чем для 
студентов СПбГУ и, наоборот: «любовь к своей профессии», «профессиональная ориентация материала» более важны для студентов СПбГУ.

В нашу анкету были включены и вопросы, касающиеся предпочтительных для студентов возраста и стиля общения преподавателей. Результаты опроса представлены на рис. 2 и 3. Для $70 \%$ студентов возраст преподавателя не имеет значения.

Демократический стиль общения выбрали $80 \%$ студентов СЗГМУ имени И. И. Мечникова. Другая картина наблюдается у студентов СПбГУ: только 35 \% выбрали демократический стиль, для $41 \%$ стиль общения преподавателя не имеет значения.
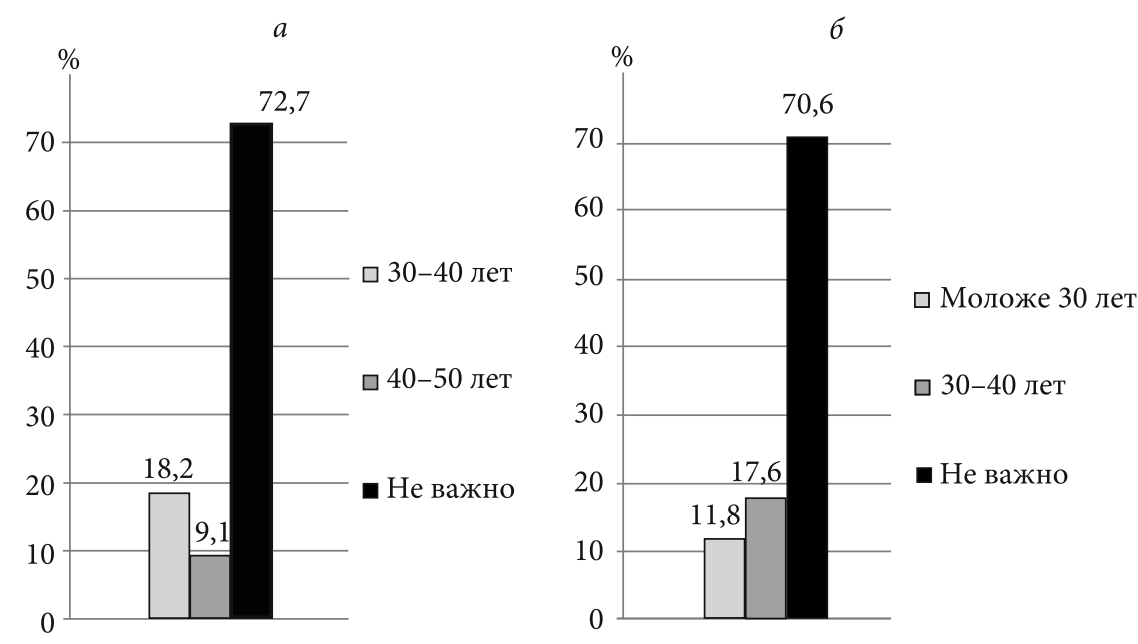

Puc. 2. Ответы студентов на вопрос о том, какой возраст преподавателя для них предпочтительнее: $a$ - студенты СЗГМУ им. И. И. Мечникова; 6 - студенты СПбГу

$a$

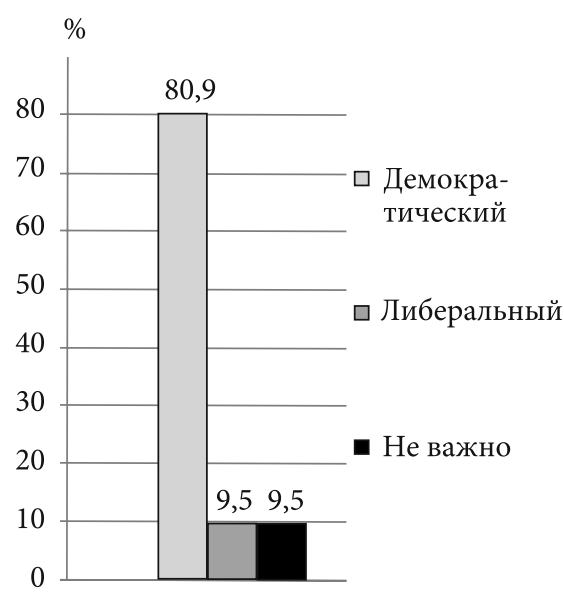

6

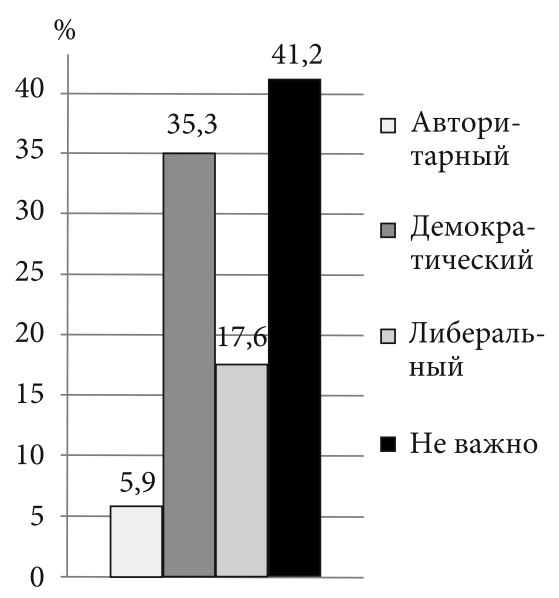

Puc. 3. Ответы студентов на вопрос о том, какой стиль общения преподавателей они предпочитают: $a$ - студенты СЗГМУ им. И. И. Мечникова; б- студенты СПбГу 
Таким образом, для студентов второго курса медицинских факультетов наиболее значимыми качествами преподавателя оказались профессионально-компетентностные и отдельные коммуникативные качества, которые помогают им учиться. Наименее значимыми оказались личностные характеристики преподавателя. Это связано с увеличением доли самостоятельной работы студентов и переходом на самообучение, так как в современном мире для этого есть все возможности. Студент воспринимает преподавателя не просто как личность, а как профессионала в своей области, который помогает будущему специалисту ориентироваться в огромном объеме современной учебной и научной информации. Преподаватель должен развивать не только свое педагогическое мастерство, но и постоянно совершенствоваться как специалист, следить за последними открытиями науки, гибко сочетать базовые знания и современные исследования в процессе обучения, демонстрировать студентам необходимость постоянно быть в курсе научных достижений, быть готовыми к непрерывному профессиональному и личностному развитию.

\section{Литература}

1. Об образовании в Российской Федерации: Федеральный закон от 29 декабря 2012 № 273-Ф3 // Российская газета. 2012. 31 дек. URL: https://rg.ru/2012/12/30/obrazovanie-dok.html (дата обращения: 01.02.2016).

2. Дадали В.А., Голованова Н.Э., Павлова Р.Н., Пономарева Р. П., Соколова Е.А., Сорокина В.С. Некоторые методические аспекты преподавания фундаментальных дисциплин в медицинском вузе на примере биоорганической и биологической химии // Вестник Северо-Западного государственного медицинского университета им. И. И. Мечникова. 2004. № 4. С. 199-201.

3. Ибрагимова Э.С. Психолого-педагогические аспекты готовности студентов медицинского вуза к профессиональной деятельности // Уникальные исследования XXI века. 2015. № 2 (2). URL: http://cyberleninka.ru/article/n/psihologo-pedagogicheskie (дата обращения: 01.02.2016).

4. Ткачева T. М. Роль личности преподавателя в обеспечении качества профессиональной подготовки выпускников вуза. М.: МАДИ, 2015. 76 с.

5. Сидаш И.С. Характеристика современного преподавателя высшей школы // Педагогическое образование в России. 2014. № 8. С. 217-222.

6. Андреева М.А. Личность преподавателя вуза как фактор формирования общекультурных и профессиональных компетенций будущих специалистов // Теория и практика образования в современном мире: материалы междунар. науч. конф. СПб.: Реноме, 2012. С. 304-306.

7. Полянская Н. М. Роль преподавателя в повышении качества образовательного процесса в высшем учебном заведении // Интернет-журнал «Мир науки». 2015. № 3. URL: http://mir-nauki.com/ PDF/48PDMN315.pdf (дата обращения: 06.07.2016).

8. Попова О. И. Преподаватель вуза: современный взгляд на профессию. Опыт социологического исследования // Педагогическое образование в России. 2012. № 6. С. 112-119.

9. Кубланов А. М. Профессионально-личностные качества преподавателя вуза как проблема педагогической науки // Вестник ТГУ. 2015. Т. 20, вып. 12 (152). С. 19-23.

Для цитирования: Голованова Н.Э., Лобанова О.А., Астратенкова И. В. Основные качества преподавателя по мнению студентов медицинских факультетов // Вестник СПбГУ. Медицина. 2017. T. 12. Вып. 1. C.104-114. DOI: 10.21638/11701/spbu11.2017.109

\section{References}

1. Ob obrazovanii v Rossiiskoi Federatsii: Federal'nyi zakon ot 29 dekabria 2012 № 273-FZ [About Education in Russian Federation: Federal law of the Russian Federation of 29 December 2012 № 273]. Rossiiskaia gazeta, 2012, December 29. Available at: https://rg.ru/2012/12/30/obrazovanie-dok.html (accessed: 01.02.2016). (In Russian)

2. Dadali V.A., Golovanova N.E., Pavlova R. N., Ponomareva R. P., Sokolova E. A., Sorokina V.S. Nekotorye metodicheskie aspekty prepodavaniia fundamental'nykh distsiplin $\mathrm{v}$ meditsinskom vuze na primere 
bioorganicheskoi i biologicheskoi khimii [Some methodological aspects of teaching fundamental disciplines in a medical higher education as an example of bioorganic and biological chemistry]. Vestnik SeveroZapadnogo gosudarstvennogo meditsinskogo universiteta im. I. I. Mechnikova [Herald of the I. I. Mechnikov Northwestern State Medical University], 2004, no. 4, pp. 199-201. (In Russian)

3. Ibragimova E.S. Psikhologo-pedagogicheskie aspekty gotovnosti studentov meditsinskogo vuza $\mathrm{k}$ professional'noi deiatel'nosti [Psycho-pedagogical aspects of a readiness of medical students to professional work]. Unikal'nye issledovaniia XXI veka [The unique research $21^{s t}$ ], 2015, no. 2 (2). Available at: http:// cyberleninka.ru/article/n/psihologo-pedagogicheskie (accessed: 01.02.2016). (In Russian)

4. Tkacheva T.M. Rol' lichnosti prepodavatelia $v$ obespechenii kachestva professional'noi podgotovki vypusknikov vuza [The role of a teacher personality to ensure the quality of training of graduates]. Moscow, MADI Publ., 2015, 76 p. (In Russian)

5. Sidash N. S. Kharakteristika sovremennogo prepodavatelia vysshei shkoly [Characteristics of a modern high school teacher]. Pedagogicheskoe obrazovanie v Rossii [Pedagogical education in Russia], 2014, no. 8, pp. 217-222. (In Russian)

6. Andreeva M.A. Lichnost' prepodavatelia vuza kak faktor formirovaniia obshchekul'turnykh i professional'nykh kompetentsii budushchikh spetsialistov [Personality of the teacher of high school as the factor of formation of general cultural and professional competence of the future specialists]. Teoriia i praktika obrazovaniia $v$ sovremennom mire: materialy mezhdunar. nauch. konf. [Theory and practice of education in the modern world: Proceedings of the international scientific conference], St. Petersburg, Renome Publ., 2012, pp. 304-306. (In Russian)

7. Polianskaia N.M. Rol' prepodavatelia v povyshenii kachestva obrazovatel'nogo protsessa $\mathrm{v}$ vysshem uchebnom zavedenii [The role of teachers in improving the quality of educational process in higher education]. Internet-zhurnal "Mir nauki" [On-line Journal "Mir nauki"], 2015, no. 3. Available at: http://mir-nauki. com/PDF/48PDMN315.pdf (accessed: 06.07.2016). (In Russian)

8. Popova O. I. Prepodavatel' vuza: sovremennyi vzgliad na professiiu. Opyt sotsiologicheskogo issledovaniia [Teacher of higher education institution: a modern view on profession. Experience of sociological research]. Pedagogicheskoe obrazovanie v Rossii [Pedagogical education in Russia], 2012, no. 6, pp. 112-119. (In Russian)

9. Kublanov A.M. Professional'no-lichnostnye kachestva prepodavatelia vuza kak problema pedagogicheskoi nauki [Professional and personal qualities of the teacher of high school as a problem of pedagogy]. Vestnik TGU, 2015, vol. 20, issue 12 (152). P. 19-23. (In Russian)

For citation: Golovanova N.E., Lobanova O.A., Astratenkova I.V. The basic teacher's qualities in opinion of the medical students. Vestnik SPbSU. Medicine, 2017, vol. 12, issue 1, pp. 103-113.

DOI: $10.21638 / 11701 /$ spbu11.2017.109

Статья поступила в редакцию 7 июля 2016 г.; принята в печать 13 декабря 2016 г.

Контактная информация:

Голованова Наталья Эриковна - кандидат биологических наук, доцент; nesh1764@mail.ru

Лобанова Ольга Алексеевна - старший преподаватель; agaf3@yandex.ru

Астратенкова Ирина Викторовна - кандидат биологических наук, доцент;

astratenkova@mail.ru

Golovanova Natalya E. — PhD, Associate Professor; nesh1764@mail.ru

Lobanova Olga A. - Senior Lecturer; agaf3@yandex.ru

Astratenkova Irina V. — PhD, Associate Professor; astratenkova@mail.ru 